DOI https://doi.org/10.30525/978-9934-26-004-9-9

\title{
ВИВЧЕННЯ РЕЛІГІЙНОГО МИСТЕЦТВА У СВІТЛІ МЕТОДІВ VISUAL CULTURE STUDIES
}

\author{
Левицька М. К. \\ кандидат мистецтвознавства, \\ дочент кафедри графічного дизайну і мистецтвва книги \\ Української академії друкарства \\ м. Львів, Україна
}

Мистецтвознавство як академічна дисципліна, розвиваючись у загальному полі гуманітарних дисциплін наприкінці XX ст., з одного боку послідовно адаптувало підходи суміжних галузей, 3 іншого намагалося вберегти «чистоту « власної методології [3, с. 16-17]. Існує упередження, що студії візуальної культури (методологія і напрям), постали як відповідь «розгніваних» істориків мистецтва на спроби «вторгнення» 3 інших дисциплін. Однак, об'єктивно, напрямок студій візуальної культури (Visual culture studies, далі - СВК) виник на перетині історії мистецтва, культурної антропології та теорії постструктуралізму, зосереджуючи свою увагу не просто на різних візуальних (в т.ч. образотворчих) формах, але на їхньому значенні у створенні контексту культури [4, с. 5; 12, с. 6-7]. Серед представників і адептів нового методологічного напрямку найвагоміший внесок здійснили такі різні дослідники як В.Т.Дж. Мітчелл, Н. Брайсон, Д. Бергер, Г. Поллок, Р. Краусс, Н. Мірзоєф, Дж. Стейсі, М. Баль [1; 9; 10; 11], значною мірою апелюючи до матеріалу «традиційної» історії мистецтва. При цьому, в основі СВК не $\epsilon$ традиційна «історична» модель (як в історії мистецтва, чи історії кіно), а модель культурної антропології [10, с. 166].

Чимало дослідників, що позиціонуються у полі методів СВК зверталися до вивчення релігійного мистецтва (Середньовіччя, Ренесансу чи Нового часу); зосереджуючись на пунктах, де візуальні об'єкти співпадають із процесами та практиками, що формують культуру [2, с. 8-21;5, с. 6-8; 6; 7; 11 ]. Водночас, треба пам'ятати, що розглядати студії візуальної культури, як історію мистецтва, взяту у розрізі культурологічних досліджень не $є$ цілком правильним.

«Перекидаючи місток» між розвинутою західною методологією та фрагментарними спробами застосувати цю методологію до українського матеріалу, спробуємо окреслити яким чином студії візуальної культури 
можуть допомогти в інтерпретації зразків релігійного мистецтва, які тривалий час були домінуючими (як кількісно, так і якісно) в загальній структурі українського мистецтва. Для цього необхідно звернутися до засобів з арсеналу СВК, оперуючи якими, можна поглибити розуміння та інтерпретацію творів образотворчого мистецтва релігійного змісту i релігійного призначення.

Студії візуальної культури переносять нашу увагу від нормативних формалізованих параметрів перегляду мистецьких творів (напр. музейних) [2, с. 10], до візуального досвіду в повсякденному житті [6]. Саме так, зміни контексту, зміни дискурсивного оточення і способів функціонування об’єктів/творів/ змінюють їх значення. Предмет візуальних досліджень включає не те, «що» зображено, а те, як «це зображення» функціонує, тобто передбачає зміщення оптики розгляду щодо традиційних об’єктів історії мистецтва [1, с. 214]. Відповідно зразки релігійного мистецтва можуть претендувати на новий розгляд у світлі вказаної методології. Вивчаючи релігійне мистецтво методами СВК дослідник встановлює, про що свідчить перевага тих чи інших іконографічних концепцій або програм, та чи інша стилістика творів, їх тематичний діапазон тощо.

Дослідники візуальної культури інтерпретують мистецькі форми релігійності не лише як артефакти, але також як втілення ідей, намірів та тлумачень: як віруючі, використовуючи візуальні засоби, формулюють i проголошують свою віру. Приміром, термін visual piety /візуальна побожність апелює до зв'язків між релігійним мистецтвом і релігійним досвідом [8], адже в релігійному режимі функціонування мистецькі об’єкти не є відділеними від глядача: глядач $є$ учасником, що тісно пов’язаний із об'єктами, які він спогладає і до яких звертається.

В такому контексті можемо прийняти за основу твердження Г. Грехема про 4 рівні зв'язків між релігійним мистецтвом, релігійною вірою i релігійним досвідом: іконографічний, дидактичний, інституційний, естетичний [8, с. 21]. На іконографічному рівні маємо ікону/релігійний образ/, що $є$ зображенням святих чи священного наративу; ікона не є важливим додатком до поклоніння/молитви, а $є$ іiі інтегральною частиною. Якщо, за твердженнями теологів, іконі належало вшанування/ veneration, і лише Богу належало поклоніння / adoration, то народна свідомість, на відміну від теологів, вважала самі ікони носіями сили і благодаті [7]. Іконографічний аспект був тісно пов'язаний із теологічним: приміром, протестантизм засвідчив перемогу вербального над візуальним у релігійному мистецтві. Дидактичний аспект пояснює важливість образу для слова, адже у самій природі людського сприйняття 
лежить краще запам'ятовування і переживання особисто побаченого, аніж почутого. Характерним прикладом є усвідомлене впровадження Тридентським собором засадничо «мистецької» доктрини Контрреформації, щоб засобами візуальних мистецтв спонукати людину до побожності і привести іiі до Бога. Щодо естетичного рівня, найкращим зразком реалізації може бути естетична стратегія релігійного мистецтва епохи бароко, з його інтелектуальною і пієтичною єдністю іконографії, де віруючий буквально «втягувався» у вихор релігійних сюжетів. Головна зміна щодо сприйняття релігійного мистецтва відбулася на рівні переходу від контемплятивного (споглядального) мистецтва молитовних роздумів, до збудженого (екстатичного) пієтизму, від нарративу до пропаганди [5, с. 192]. Схеми і поступовий розвиток образотворчих сюжетів бароко формувалися подібно до проповіді; в бароковому храмі усі структурні елементи мали як просторове, так і алегоричне значення (колони і пілястри - підкріплююча сила віри; більшість барокових вівтарів, завантажених образами і символами артикулювали Христоцентричну посвяту тощо) [11]. Образотворче мистецтво, у його найширшому сенсі, стало істотним елементом у новому виді персональної взаємодії з сакральним.

Підсумовуючи, можна зазначити, що методи студій візуальної культури у міждисциплінарній сфері вивчення матеріальних мистецьких форм та чуттєвих (візуальних та ментальних) висловлювань віри розкривають новий потенціал в дослідженні творів релігійного мистецтва. В такому ракурсі до поля зору мистецтвознавчого дослідження потрапляють не лише традиційні мистецькі об'єкти 3 високими естетичними вартостями, а й пласт популярних зразків «середнього» рівня, наділених владою впливу на широкі маси вірних. В цьому контексті набувають актуальності такі поняття як візуальна нормативність, статус, автономність зображень, прийнятих або адаптованих до релігійних потреб.

\section{Література:}

1. Баль, Мике (2012). Визуальный эссенциализм и обьект визуальных исследований, Логос, 1(85), с. 212-249 URL: http://www.logosjournal.ru/arch/23/art_124.pdf

2. Buggeln, G., Paine, C., \& Plate, S. B. (Eds.). (2017). Religion in museums: global and multidisciplinary perspectives. Bloomsbury Publishing.

3. d'Alleva, A. (2005). Methods and theories of art history. Laurence King Publishing. 
4. Filipová, M., \& Rampley, M. (Eds.). (2007). Možnosti vizuálních studii: obrazy, texty, interpretace. Společnost pro odbornou literaturu-Barrister \& Principal.

5. Freedberg, D. (1989). The power of images: Studies in the history and theory of response Chicago: University of Chicago Press.

6. Freedberg, David. Holy images and other images, URL:http://www.columbia.edu/cu/arthistory/faculty/Freedberg/Holy-ImagesOther-Images.pdf

7. Garnett, J., \& Rosser, G. (2013). Spectacular miracles: Transforming images in Italy from the Renaissance to the present. Reaction Books.

8. Graham, H. (2006). The art of the sacred: an introduction to the aesthetics of art and belief. IB Tauris.

9. Mirzoeff, N. (2009). An Introduction to Visual Culture (2d ed.). London\&New York.

10. Mitchell W.T.J. (2005). What Do Pictures Want? (The Lives and Loves of Images). Chicago

11. Plate, S. B. (2002). Religion, art, and visual culture: a cross-cultural reader. Palgrave.

12. Rampley, M. (2005). Exploring visual culture: Definitions, concepts, contexts. Edinburgh University Press.

DOI https://doi.org/10.30525/978-9934-26-004-9-10

\title{
МИСТЕЦТВО АНІМАЦІЇ У ЦИФРОВУ ЕПОХУ
}

\author{
Мараховська К. Д. \\ аспірантка кафедри мистецтввознавства \\ та загальногуманітарних дисииплін \\ Міжнародного гуманітарного університету \\ м. Одеса, Україна
}

Анімаційне мистецтво розвивається і трансформується під впливом загальнокультурних та технологічних змін. Удосконалюються технічні можливості, змінюються виражальні засоби, формується нова естетика.

3 появою сучасних цифрових технологій функціонування анімації у культурному просторі набуло нових форм. Анімація перетворилась на загальновживаний елемент у багатьох сферах. Спостерігається іiі використання у більш широкому контексті - від рекламної продукції до бізнес презентації. 